PRÁVNE ROZPRAVY ON-SCREEN II. - Sekcia súkromného práva

online vedecká konferencia - 13. november 2020

\title{
PÁR POZNÁMOK K ZAMÝŠLANÝM LEGISLATÍVNYM ZMENÁM ZÁKONA O RODINE
}

\section{A FEW REMARKS ON THE INTENDED LEGISLATIVE CHANGES}

\section{TO THE FAMILY ACT}

Kristína Malá Piovarčíová1

DOI: https://doi.org/10.24040/pros.13.11.2020.ssp.125-137

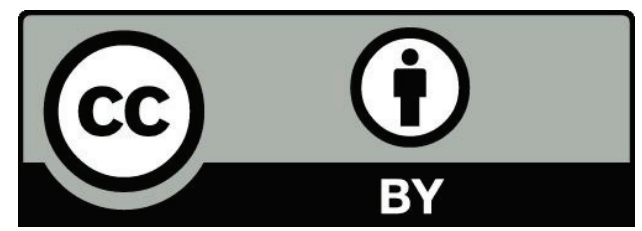

\begin{abstract}
Abstrakt
Príspevok sa venuje zamýšl'aným legislatívnym zmenám Zákona o rodine, ktoré si dávajú za ciel' posilnit' vnímanie diet’at’a ako subjektu a nie objektu právnych vzt’ahov, zakotvit' inštitút rodinného plánu a detského advokáta ex offo, zaviest' koncept tzv. konfliktu lojality a odcudzujúceho správania, či deetatizovat' kolizneho opatrovníka, čomu by zodpovedali aj adekvátne zmeny civilných procesných kódexov a trestnoprávnych predpisov.
\end{abstract}

\section{Kl’účové slová}

Maloleté diet’a. Kolízny opatrovník. Rodinný plán. Najlepší záujem maloletého diet’at’a.

\begin{abstract}
Paper deals with the intended legislative changes to the Family Act, whoch aim to strengthen the perception of the child as a subject and not an object of legal relations, to anchor institute of family plan and children's lawyer ex offo, to introduce the concept of so-called conflict of loyalty and condemning behavior, or to de-statise the gardian, which would be matched by adequate changes to civil precedural codes and criminal law.
\end{abstract}

\section{Keywords}

Minor child. Guardian. Family plan. The best interest of the child.

\footnotetext{
${ }^{1}$ JUDr. Kristína Malá Piovarčíová - absolvent Právnickej fakulty UPJŠ v Košiciach (2005), advokát od roku 2009, študent 4. ročníka externého doktorandského štúdia na Právnickej fakulte UPJŠ v Košiciach
} 


\section{PRÁVNE ROZPRAVY ON-SCREEN II. - Sekcia súkromného práva}

online vedecká konferencia - 13. november 2020

\section{Úvod}

V ostatnom roku sa popri stále často diskutovanej téme striedavej osobnej starostlivosti dostáva do popredia pozornosti odbornej verejnosti i médií tzv. interdisciplinárna spolupráca založená na princípoch Cochemskej praxe. Je to spôsobené tým, že na prelome rokov 2018/2019 sa na vybraných súdoch Slovenskej republiky začalo s testovaním pilotného projektu, ktorý si dal za ciel' dosiahnut' nielen rýchlejšie rozhodovanie vo veciach maloletých detí, ale zároveň aj kvalitnejšie rozhodovanie. Trvanie tohto pilotného projektu je určené do 31.12.2020, ale už dnes možno skonštatovat', že prispel k otvoreniu témy nevyhnutnej zmeny $\mathrm{v}$ prístupe $\mathrm{k}$ slovenskej poručenskej agende. Táto je dlhodobo podceňovaná a prehliadaná, jej stav je nevyhovujúci a čoraz viac kritizovaný, a to aj napriek tomu, že je jednou z najt'ažších a najdôležitejších, lebo rozhoduje o det'och, o budúcnosti každej spoločnosti. Dnešná spoločenská situácia so sebou prináša neustály nárast nápadu rodinnoprávnych vecí na súdoch, ktoré nedokážu pružne a účinne poskytnút' riešenie rodinného konfliktu v súlade s najlepším záujmom maloletých detí.

Výrazné snahy o zmenu $\mathrm{v}$ rodinnoprávnej agende možno aktuálne badat' $\mathrm{v}$ procesnoprávnej rovine vrátane organizačných zmien na súdoch, ako aj v rovine hmotnoprávnej.

V posledných dňoch bola verejnosti predstavená tzv. nová súdna mapa, ku ktorej sa Ministerstvo spravodlivosti Slovenskej republiky rozhodlo pristúpit' pri reforme súdnictva s ciel'om zvýšit' jeho dôveryhodnost', výkon a kvalitu, a to aj na základe špecializácie sudcov. Špecializácia sudcov sa predpokladá pre trestnú, civilnú, rodinnú a obchodnú agendu na všeobecných súdoch a pre správnu agendu v samostatnom správnom súdnictve. ${ }^{2}$

$\mathrm{Na}$ to nadväzujú zamýšl’ané legislatívne zmeny v hmotnoprávnej úprave rodinného práva obsiahnutej $\mathrm{v}$ Zákone o rodine ${ }^{3}$. Rekodifikačné práce súkromného práva, ktoré prebiehajú už niekol'ko rokov sa okrem iného venujú aj otázkam inkorporovania rodinného práva do jedného kódexu - do nového Občianskeho zákonníka alebo ponechania dvoch samostatných kódexov. Je nepochybné, že ide o zaujímavú tému do diskusie, ale tento príspevok si dáva za ciel’ predstavit’ aktuálne zamýšl’ané legislatívne zmeny Zákona o rodine,

\footnotetext{
${ }^{2} \mathrm{~S}$ návrhom novej súdnej mapy sa už oboznamuje odborná verejnost' URL: $<$ https://www.najpravo.sk/clanky/snavrhom-novej-sudnej-mapy-sa-uz-oboznamuje-odborna-verejnost.html>. [online].[cit. 24.11.2020].

${ }^{3}$ zákon č. 36/2005 Z.z. Zákon o rodine ${ }^{3}$ a o zmene a doplnení niektorých zákonov v znení neskorších právnych predpisov
} 


\section{PRÁVNE ROZPRAVY ON-SCREEN II. - Sekcia súkromného práva}

online vedecká konferencia - 13. november 2020

ktoré by mali prispiet' k väčšej ochrane práv maloletých detí, ale aj k efektívnej realizácii výkonu rodičovských práv a povinností k nim.

\section{Diet’a ako subjekt práva}

Deti sú plnohodnotnými členmi každej spoločnosti. $O$ to zarážajúcejším je frekventovaný prístup k maloletým det’om ako k objektom právnych vzt'ahov, či dokonca ako k predmetom vlastníctva, o ktorých sa rozhoduje bez dôkladného posúdenia toho, čo je pre nich najlepšie. Tento prístup je častokrát zretel'ný zo správania sa preferenčného rodiča, ktorý si svoje subjektívne predstavy zamieňa s dobrom svojho diet'at’a, ale nie je ojedinelý ani mechanický prístup súdu k poručenskej veci bez dôkladného posúdenia špecifík prejedávanej veci v súlade s najlepším záujmom diet’at’a ako prioritným hl'adiskom pri svojom rozhodovaní.

Zvýraznenie uvedeného ponímania postavenia diet’at'a $\mathrm{v}$ právnych vzt'ahoch má byt' vyslovene premietnuté aj do základnej zásady Zákona o rodine obsiahnutej v čl. I, v zmysle ktorej je diet’a je svojbytnou a rovnoprávnou súčast’ou rodiny s právami a povinnost’ami, zodpovedajúcimi jeho schopnostiam a možnostiam. Táto zásada vhodne doplní znenie čl. 4 Zákona o rodine, ktorý sa tým stane úplným a aj legálnym textom zareaguje na dlhodobý celosvetový trend v ochrane práv detí.

Diet'a je nutné vnímat' ako rovnocenného jedinca, ktorému patria nielen všeobecné l’udské práva a slobody, ale zároveň s prihliadnutím na jeho špecifickost' v biologických, fyziologických, psychických, či emocionálnych odlišnostiach v porovnaní s dospelým jedinca aj práva zvláštne, a to práva detí.

Prvýkrát v medzinárodných dokumentoch zadefinoval pojem diet’a Dohovor o právach diet’at’a prijatý Organizáciou spojených národov dňa 20.11.1989 v New Yorku, ktorý v čl. 1 zakotvil, že diet'at'om sa rozumie každá l'udská bytost' do 18 rokov veku, pokial' nedosiahla plnoletost' skôr ${ }^{4}$. Naša vnútroštátna hmotnoprávna ani procesnoprávna úprava legálnu definíciu pojmu maloleté diet'a nevymedzuje, napriek tomu že obsahuje termíny diet’a a maloleté diet’a. V Občianskom zákonníku je uvedený len okamih, kedy sa človek stáva spôsobilým na právne úkony. V zmysle ust. $\S 8$ ods. 1 Občianskeho zákonníka spôsobilost'

\footnotetext{
${ }^{4}$ Dohovor o právach diet'at'a [online].[cit. 24.11.2020].

URL: $<$ https://www.unicef.sk/files/dohovor_o_pravach_dietata.pdf $>$.
} 


\section{PRÁVNE ROZPRAVY ON-SCREEN II. - Sekcia súkromného práva}

online vedecká konferencia - 13. november 2020

fyzickej osoby vlastnými právnymi úkonmi nadobúdat' práva a brat' na seba povinnosti vzniká v plnom rozsahu plnoletost'ou. Na to nadväzuje ods. 2, ktorý zakotvuje, že plnoletost' sa nadobúda dovŕšsením osemnásteho roku. Táto veková hranica je rovnaká u obidvoch pohlaví. ${ }^{5}$ Pred dosiahnutím tohto veku sa plnoletost' nadobúda uzavretím manželstva a takto nadobudnutá plnoletost' sa nestráca ani zánikom manželstva ani vyhlásením manželstva za neplatné. Za základe vyššie uvedeného možno skonštatovat', že maloletým diet’at'om sa rozumie fyzická osoba od narodenia po dosiahnutie plnoletosti.

\section{Deetatizácia kolízneho opatrovníka}

V zmysle ust. $§ 9$ Občianskeho zákonníka ${ }^{6}$ majú maloletí spôsobilost’ len na také právne úkony, ktoré sú svojou povahou primerané rozumovej a vôl'ovej vyspelosti zodpovedajúcej ich veku. S prihliadnutím na uvedené musia byt' maloleté deti zastúpené, pričom toto zastúpenie vzniká na základe zákona. ${ }^{7}$ Podl’a $§ 27$ ods. 1 Občianskeho zákonníka v spojení s $\$ 31$ Zákona o rodine rodičia zastupujú maloleté diet’a v tých právnych úkonoch, na ktoré nie je spôsobilé. To neplatí, ak ide o právne úkony, pri ktorých môže vzniknút' kolízia záujmov. V tomto prípade súd ustanoví maloletému diet’atu kolízneho opatrovníka. Kolízneho opatrovníka ustanoví súd aj v prípade, že zákonný zástupca nemôže maloleté diet’a zastupovat' lebo mu v tom bránia vážne dôvody alebo ak maloleté diet’a nemá zákonného zástupcu. Z uvedeného je zrejmé, že kolízny opatrovník môže byt' tak hmotnoprávnym, ako aj procesnoprávnym opatrovníkom. ${ }^{8}$

Zákon o rodine pre tieto prípady zaviedol pojem kolízny opatrovník. Ide o procesného opatrovníka „ad hoc“ pre určité konkrétne konanie alebo pre určitý právny úkon, ktorého funkcia zaniká právoplatným ukončením konania alebo vykonaním právneho úkonu. Tento inštitút predstavuje verejnoprávny prvok v súkromnoprávnej úprave rodinného práva. Ide o prejav zvýšenej ochrany, ktorú požívajú maloleté deti, pričom stačí aj potenciálna možnost' vzniku kolízie záujmov. Súd môže ustanovit’ kolízneho opatrovníka v štyroch prípadoch: ak

\footnotetext{
${ }^{5}$ VOJČÍK, P. a kol. Občianske právo hmotné. 1. vydanie. Plzeň: Aleš Čeněk, 2012. 113 s. ISBN 978-80-7380$402-2$

${ }^{6}$ zákon č. 40/1964 Zb. Občiansky zákonník v znení neskorších právnych predpisov

${ }^{7} \S 22$ a nasl. Občianskeho zákonníka

8 JURČOVÁ, M. A kol. Zastúpenie v súkromnom práve. 1. vydanie. Praha: C. H. Beck, 2012. 121 s. ISBN 97880-7400-420-9
} 


\section{PRÁVNE ROZPRAVY ON-SCREEN II. - Sekcia súkromného práva}

online vedecká konferencia - 13. november 2020

hrozí rozpor záujmov medzi rodičom ako zákonným zástupcom a maloletým diet’at’om ako zastúpeným, ak hrozí rozpor záujmov medzi viacerými det’mi rodiča, ktorý je ich zákonným zástupcom, ak maloleté diet’a nemá zákonného zástupcu, ak maloleté diet’a má zákonného zástupcu, ale zákonnému zástupcovi bránia vážne dôvody, aby za maloleté diet’a konal. ${ }^{9}$

Po podaní návrhu na začatie konania súd preskúma podmienky konania a následne vydá uznesenie, v ktorom ustanoví maloletému diet’at’u na zastupovanie v konaní kolízneho opatrovníka, a to príslušný úrad práce, sociálnych vecí a rodiny. Kolízny opatrovník má v konaní pred súdom postavenie účastníka konania, čo ho oprávňuje zúčastnit'sa pojednávaní, vyjadrovat' sa ku všetkým skutočnostiam, ktoré vyšli v konaní najavo, navrhovat' dôkazy, ako aj navrhovat' súdu, ako má vo veci rozhodnút' s prihliadnutím na záujem diet'at'a a názor diet'at’a k prejednávanej veci. Spravidla súd v tomto uznesení uloží kolíznemu opatrovníkovi, aby v stanovenej lehote prešetril pomery na strane maloletého diet'at'a, uskutočnil pohovor s maloletým diet’at'om a podal o tom súdu písomnú správu, ktorá bude obsahovat' aj odporúčanie kolízneho opatrovníka vo vzt’ahu k meritu prejednávanej veci. Zároveň zvykne súd kolíznemu opatrovníkovi uložit' zistit’ rozumovú vyspelost' diet’at’a na účely postupu súdu podl'a ust. $\$ 116$ Civilného mimosporového poriadku ${ }^{10}$, ktoré súdu ukladá povinnost' informovat' maloleté diet’a o prebiehajúcom konaní a objasnit' mu dôsledky súdneho rozhodnutia vo veci. Proti tomuto uzneseniu nie je prípustné odvolanie ${ }^{11}$.

Súd v drvivej väčšine prípadov ustanoví za kolízneho opatrovníka práve orgán sociálnoprávnej ochrany detí a sociálnej kurately, aj ked’ z dikcie §117 Civilného mimosporového poriadku ${ }^{12}$ vyplýva, že ak treba, aby za maloletého konal opatrovník, súd na návrh ustanoví za opatrovníka najmä blízku osobu maloletého, u ktorej je predpoklad, že bude konat' v záujme maloletého, ak s ustanovením súhlasí. Inak ustanoví za opatrovníka orgán sociálnoprávnej ochrany detí a sociálnej kurately. Je to z dôvodu, že ustanovenie blízkej osoby alebo inej osoby v obdobnom vzt’ahu (napr. triedny učitel') za kolízneho opatrovníka maloletého by $\mathrm{v}$ praxi prinášalo komplikácie súvisiace napr. pri realizácii šetrenia $\mathrm{v}$ domácnosti rodiča, pri zist'ovaní názoru diet'at'a a podobne.

Zákon o sociálnoprávnej ochrane detí a sociálnej kuratele ${ }^{13} \mathrm{v} \S 73$ ods. 2 písm. b) bod 2 v spojení s $\$ 90$ ods. 4 písm. a) stanovuje, že funkciu kolízneho opatrovníka vykonáva úrad

\footnotetext{
${ }^{9}$ PAVELKOVÁ, B. Zákon o rodine. Komentár. 1. vydanie. Praha: C. H. Beck, 2011. 177 s. ISBN 978-80-7400$359-2$

${ }^{10}$ zákon č. 161/2015 Z.z. Civilný mimosporový poriadok v znení neskorších právnych predpisov

${ }^{11}$ porovnaj \$357 Civilného sporového poriadku v spojení s $\$ 59$ Civilného mimosporového poriadku

${ }^{13}$ zákon č. 305/2005 Z.z. o sociálnoprávnej ochrane detí a sociálnej kuratele v znení neskorších predpisov
} 


\section{PRÁVNE ROZPRAVY ON-SCREEN II. - Sekcia súkromného práva}

online vedecká konferencia - 13. november 2020

práce, sociálnych vecí a rodiny podl'a osobitného predpisu. Podl'a tohto zákona sa miestna príslušnost' úradu práce, sociálnych vecí a rodiny spravuje sídlom úradu práce, sociálnych vecí a rodiny, v ktorého obvode má diet’a obvyklý pobyt.

Širšie predstavenie inštitútu kolízneho opatrovníka má viest' k pochopeniu jeho nezastupitel'ného miesta v ochrane maloletých detí, ktoré funkcie sa mu darí napĺn̆at’ aj tým, že sú zverené do rúk orgánov štátnej správy. Do budúcna sa ráta s prenesením kompetencií kolízneho opatrovníka na mimovládne organizácie, akreditované subjekty ako subjekty vykonávajúce opatrenia sociálnoprávnej ochrany detí a sociálnej kurately. Obdobný postup bol v minulosti zakotvený aj pri sprostredkovaní náhradnej starostlivosti, pri ktorom niektoré z opatrení sociálnoprávnej ochrany detí a sociálne kurately začali realizovat' akreditované subjekty. Súčasnú zat’aženost' a personálnu poddimenzovanost' úradov práce sociálnych vecí a rodiny by však bolo vhodnejšie riešit' posilnením materiálneho zabezpečenia i personálnych kapacít týchto inštitúcií vrátane ich pravidelného vzdelávania než zverením ich funkcií subjektom mimo sústavy orgánov štátnej správy. Vytvára to priestor pre roztrieštenost' postupov, ako aj spomínané komplikácie pri oprávnenosti vykonávania miestnych šetrení a zist'ovania názoru detí. To však nevylučuje možnost' zverenia časti úloh úradov práce, sociálnych vecí a rodiny akreditovaným subjektom, čo sa osvedčilo napríklad vo sfére poradensko-psychologického poradenstva pri realizácii výchovných opatrení. Úplný presun právomocí orgánov štátnej správy na neštátne subjekty alebo ich súčasné pôsobenie zrejme nepovedie k vytvoreniu priestoru pre efektívnejšiu ochranu práv detí.

\section{Detský advokát ex offo}

Pri výkone funkcie kolízneho opatrovníka je prvoradým hl’adiskom najlepší záujem diet'at'a ${ }^{14}$. Je to prvá osoba, s ktorou je diet'a v osobnom kontakte, ktorá diet’a zastupuje, háji jeho záujmy a chráni ho. V právnej teórii neexistuje definícia princípu najlepšieho záujmu diet'at'a, preto je potrebné vychádzat' z okolností konkrétneho prípadu. ${ }^{15}$ Kolízny opatrovník spozná domáce prostredie diet’at’a vlastným šetrením na mieste samom, spozná rodičov diet'at'a pri ich osobnom pohovore, čo mu dáva možnost' zohl'adňovat' jednotlivé konkrétne okolnosti každého prípadu v zmysle zásady, že najlepší záujem jedného diet’at’a sa nerovná

\footnotetext{
${ }_{14}^{14}$ porovnaj $\$ 3$ ods. 3 zákona č. 305/2005 Z.z. o sociálnoprávnej ochrane detí a sociálnej kuratele

15 porovnaj napr. Nález Ústavného súdu SR sp. zn. I. ÚS 298/2018 z 2. 7.2019
} 


\section{PRÁVNE ROZPRAVY ON-SCREEN II. - Sekcia súkromného práva}

online vedecká konferencia - 13. november 2020

najlepšiemu záujmu iného diet’at’a, a na základe toho tlmočit' svoje stanovisko k prejednávanej veci súdu. Kolíznym opatrovníkom je mnohokrát vyčítaný mechanický prístup k jednotlivým prípadom, nedostatočnú angažovanost', čo je dané jednak samotným rozpoložením rodičov nachádzajúcich sa spravidla v akútnej fáze rozchodu alebo inej t’ažkej životnej situácii, ako aj načrtnutou všeobecnou poddimenzovanost'ou úradov práce, sociálnych vecí a rodiny.

Zrejme v snahe o posilnenie ochrany detí sa do budúcna zvažuje v Zákone o rodine zavedenie inštitútu právneho zástupcu diet’at’a, ktorého by diet’at’u ustanovil súd popri opatrovníkovi. Na túto hmotnoprávnu úpravu by mala nadväzovat' procesná úprava, v zmysle ktorej ak je účastníkom konania či stranou sporu maloleté diet’a súd vždy ustanoví advokáta, ktorý bude maloleté diet’a zastupovat' popri opatrovníkovi.

Určitú paralelu možno vidiet' v novele Trestného poriadku, účinnej od 01.01.2019, ktorá zaviedla inštitút opatrovníka poškodeného z radov advokátov za účelom výkonu práv poškodeného, ktorý ich nemôže alebo nevie realizovat' sám, a to v snahe zabezpečit' poškodeným vyššiu ochranu ich práv. Prax ukázala, že vo väčšine prípadov ustanovenie opatrovníka neprinieslo reálnu ochranu a zabezpečenie práv poškodeného, lebo ide len o formálne zastupovanie, pritom táto funkcia nie je vykonávaná bezplatne, teda týmto titulom vznikajú trovy uhrádzané advokátom zo strany štáut.

Nie je jasné, z akého dôvodu má byt' diet’a zastúpené kolíznym opatrovníkom a ustanoveným advokátom súčasne, aký to bude mat' praktický význam a podobne. Uvedená duplicita sa javí byt' nadbytočná a v skutočnosti zrejme neprispeje ku zvýšenej ochrane práv maloletých detí ako tomu bolo doposial', pri súčasnom vynakladaní finančných prostriedkov zo štátneho rozpočtu na úhradu trov právneho zastupovania.

\section{Rodinný plán}

V Českej republike sa pri interdisciplinárnej spolupráci založenej na princípoch Cochemskej praxe pracuje s rodičovskými plánmi, ktoré si rodičia zostavujú, dokonca na nich participujú aj samotné deti a sú prílohou rozhodnutia súdu alebo súčast’ou súdneho spisu. Na Slovensku sa zatial' k využívaniu rodičovských plánov nepristúpilo, čo možno hodnotit’ ako negatívum z pohl'adu zabezpečenia akceptácie rozhodnutia rodičmi a jeho dlhodobej 


\section{PRÁVNE ROZPRAVY ON-SCREEN II. - Sekcia súkromného práva}

online vedecká konferencia - 13. november 2020

udržatel'nosti. Rodičovský plán tvorí niekol'kostranový dotazník, v ktorom sa riešia jednotlivé životné situácie voblasti starostlivosti o maloleté diet’a ako napríklad bývanie, školská dochádzka, výber školy, záujmové aktivity, zdravotná starostlivost', finančné záležitosti a d'alšie otázky, a to od základnej komunikácie rodičov cez špecifické okolnosti v období vývoja diet’at'a ${ }^{16}$. Každý z rodičov vyplní samostatne svoj rodičovský plán a častokrát pri jeho porovnaní s rodičovským plánom druhého rodiča pre súdom alebo u kolízneho opatrovníka zistí, že jeho názory na budúce usporiadanie vzt’ahov nie sú až tak odlišné ako sa spočiatku zdalo, že sa v mnohom zhodujú, ale pre vzájomný konflikt neboli schopní konštruktívnej komunikácie ohl'adom ich spoločného diet'at'a. V sporných otázkach sa následne rodičia snažia nájst' za pomoci odborníka konsenzus. Zároveň tento plán rieši situácie, ktoré nastanú až po rozhodnutí súdu, teda nie sú dané v čase rozhodovania. Náležitosti rodinného plánu nie sú zakotvené v zákone. Rodinný plán si rodičia spisujú popri rodičovských dohodách, ktoré uzatvárajú v prevažnej väčšine v modeli interdisciplinárnej spolupráca založenej na princípoch Cochemskej praxe, ktorá je v Českej republike na vybraných súdoch zavedená od roku 2016.

V slovenskom právnom poriadku sa pri zamýšl’aných legislatívnych zmenách siaha po tzv. rodinnom pláne, ale v značne odlišnom prístupe ako je vyššie načrtnutý postup v Českej republike. Zrejme pôjde len o jazykovú príbuznost' oboch názvov týchto inštitútov, lebo ich právna úprava i funkcia budú iné. Zákonodarca plánuje nahradit’ rodičovské dohody a samotné výroky o úprave výkonu rodičovských práv a povinností k maloletým det’om práve inštitútom rodinného plánu. V ust. §24 Zákona o rodine sa plánuje zakotvit', že v rozhodnutí, ktorým sa rozvádza manželstvo rodičov maloletého diet’at’a súd upraví výkon práv a povinností medzi rodičom a diet’at'om na základe rodinného plánu. Ak takého plánu niet, súd po márnej výzve na predloženie rodinného plánu ustanoví spôsob ako sa rodinný plán zostaví, najmä prizve opatrovníka, právneho zástupcu maloletého a d’alších odborníkov a upraví výkon práv a povinností na základe tohto zákona spôsobom, aby diet'at'u zostali zachované čo najrovnomernejšie rodinné väzby, ak nie sú dôvody osobitného zretel'a., ktoré by vyžadovali inú úpravu. Na to by mala nadväzovat' špecifikácia náležitostí rodinného plánu, v zmysle ktorej rodinný plán musí obsahovat':

a) vymedzenie relevantných prvkov najlepšieho záujmu diet’at’a, ich konkrétneho obsahu a priradenie váhy každému z nich vo vzt’ahu k ostatným,

16 pozri https://www.justice.cz/documents/39769/1552991/Tiskopis+-+Rodičovský+plán.pdf/15739d2e-655640cd-9a38-cce372635396 


\section{PRÁVNE ROZPRAVY ON-SCREEN II. - Sekcia súkromného práva}

online vedecká konferencia - 13. november 2020

b) spôsob osobnej starostlivosti, ktorý bude zohl'adňovat' vôl'u a potreby maloletého diet'at'a,

c) spôsob zabezpečenia súčinnosti, aby sa naplnila povinnost' diet'at'a so svojimi rodičmi v záujme starostlivosti o neho a jeho výchovu podl'a $\$ 43$ tohto zákona, pričom treba dbat' o to, aby kontakt medzi diet'at'om a rodičom bol najmenej $40 \%$ mesačného časového fondu, ak sa nedohodne inak

d) spôsob hmotného zabezpečenia diet'at'a a starostlivosti o jeho majetok, osobitne výšku a spôsob platenia výživného

e) určenie trvalého bydliska

f) spôsob mimosúdneho riešenia sporov medzi rodičmi súvisiacich s rodinným plánom

Podl'a zamýšl’aných legislatívnych zmien súčast'ou návrhu na rozvod manželstva musí byt' rodinný plán o usporiadaní rodinných vzt’ahov medzi rodičmi a diet’at'om po rozvode manželstva. Rodinný plán o usporiadaní vzt’ahov medzi rodičmi a diet’at'om sa stane súčast'ou rozhodnutia o rozvode. Ak sa zmenia pomery, súd môže aj bez návrhu zmenit’ rodinný plán o usporiadaní vzt'ahov medzi rodičmi a diet'at'om v zmysle tohto zákona. Dohoda o výkone rodičovských práv a povinností sa nahrádza rodinným plánom o usporiadaní vzt'ahov medzi rodičmi a diet'at'om.

Z naznačeného sa javí byt' zamýšlaný inštitút rodinného plánu určitým hybridom rodičovskej dohody a rodičovského plánu. Pojem plán evokuje víziu do budúcna, plán na najbližšie roky, čo fakticky mala napĺn̆at’ aj rodičovská dohoda a samotná zmena názvu tohto inštitútu nepovedie k odstráneniu aktuálnych problémov pri schval'ovaní rodičovských dohôd ako je napríklad ich vykonatel’nost'. Znenie rodinného plánu musí byt' konkrétne, určité, zrozumitel'né a vyšpecifikované tak, aby v prípade jeho neplnenia mohol byt' predmetom exekučného konania alebo konania o výkon rozhodnutia.

Tento stav bolo možné vyriešit' precizovaním právnej úpravy rodičovských dohôd, ako aj rozšírením výrokov samotných autoritatívnych rozhodnutí súdov o úprave výkonu rodičovských práv a povinností k maloletým det’om, t.j. pripustit’ aj iné výroky, ktoré sa s ohl'adom na spoločenský vývoj stávajú bežnými a potrebnými pre bezproblémové fungovanie výkonu rodičovských práv a povinností $\mathrm{k}$ maloletému diet'at'a (nielen formu starostlivosti o diet’a, výšku výživného a frekvenciu styku, ale aj d’alšie dojednania týkajúce 


\section{PRÁVNE ROZPRAVY ON-SCREEN II. - Sekcia súkromného práva}

online vedecká konferencia - 13. november 2020

sa informačnej povinnosti, poberania prídavku na diet’a, uplatňovania si daňového bonusu, miesta trvalého pobytu diet'at'a, úhrady mimoriadnych výdavkov na diet’a, styku diet'at'a so širšou rodinou, či konkrétnych výchovných postupov). Vhodné by to bolo doplnit' po vzore Českej republiky rodičovskými plánmi, ktoré by sa nestali súčast'ou výroku rozsudku súdu, boli by skonštatované v odôvodnení samotného súdneho rozhodnutia a boli by súčast'ou súdneho spisu, čo má nepochybne význam v prípadnom budúcom d’alšom konaní o zmenu tohto rozhodnutia pri kvalifikovanej zmene pomerov na strane účastníkov konania.

\section{Konflikt lojality a vymazávanie rodičov}

V ostatnej dobe sa z médií čoraz častejšie zoznamujeme s termínom tzv. vymazávania rodičov, na čo upozorňujú rodičia, ktorým je bránené v styku s ich det’mi. Preferenčný rodič, teda rodič, ktorému je diet'a zverené do osobnej starostlivosti, častokrát úmyselne marí styk diet’at'a s druhým rodičom svojim priamym konaním, ale aj nepriamo tým, že ponechá realizáciu styku na vôl'u detí, ktoré logicky v snahe mu vyhoviet' ako preferenčnému rodičovi, začínajú styk s druhým rodičom podmieňovat' rôznymi ústupkami $\mathrm{z}$ jeho strany alebo bezdôvodne odmietat'. Týmto ciel’avedomým pôsobením programujúceho rodiča dochádza k vzniku syndrómu zavrhnutého rodiča. Správanie sa detí a ich mienkotvorný proces je determinovaný prostredím v ktorom žijú a príčinou ich začínajúceho negatívneho vzt'ahu k druhému rodičovi je výsledkom vplyvu preferenčného rodiča, s ktorým žijú, pokial' nejde o situáciu, že tento stav zavinil samotný rodič oprávnený k styku s diet’at’om. Deti sa častokrát dostávajú do konfliktu lojality, ktorý predstavuje vnútorný konflikt, ktoré prežíva diet’a, ak sa má priklonit' na stranu jedného z rodičov. Diet'a túži byt' $\mathrm{s}$ obomi rodičmi a pri sporoch rodičov sa snaží vyhoviet' obom.

Túto alarmujúcu situáciu sa nedarí riešit' v konania o výkon rozhodnutí v zmysle Civilného mimosporového poriadku a vykonávacej vyhlášky ${ }^{17}$, ktoré sú málo efektívne. V nadväznosti na to ostáva nefunkčný aj postup v zmysle ust. §349 Trestného zákonu pri vyvodzovaní trestnoprávnej zodpovednosti za páchanie trestného činu marenia výkonu úradného rozhodnutia. V praxi to znamená, že rodič, ktorý marí styk druhého rodiča nie je pre nedostatočnú právnu úpravu a efektivitu konania za svoje konanie sankcionovaný, zároveň

17 vyhláška MS SR č. 207/2016 Z.z., ktorou sa ustanovujú podrobnosti výkonu rozhodnutia vo veciach maloletých 


\section{PRÁVNE ROZPRAVY ON-SCREEN II. - Sekcia súkromného práva}

online vedecká konferencia - 13. november 2020

oprávnený rodič sa nevie domôct' styku s diet’at'om, lebo súdy nariad’ujú výkon rozhodnutia a následné odňatie diet’at’a len v ojedinelých prípadoch.

Sanovat' riziko vymazávania rodičov má zakotvenie konceptu „konflikt lojality a odcudzujúce správanie“ cez Zákon o rodine aj do iných zákonov, vrátane posilnenia vymožitel'nosti práva zavedením trestnoprávnej a priestupkovej zodpovednosti, čo možno hodnotit' jednoznačne pozitívne.

Doplnenie ust. $\$ 208$ ods. 1 Trestného zákona ${ }^{18}$, kde do skutkovej podstaty trestného činu týrania blízkej a zverenej osoby podl’a $\$ 208$ ods. 1 má byt' doplnené, že kto blízkej osobe alebo osobe, ktorá je v jeho starostlivosti alebo výchove, spôsobí fyzické utrpenie alebo psychické utrpenie vyvolávaním konfliktu lojality u maloletého diet'at'a po dlhšiu dobu alebo vystavením odcudzujúcemu správaniu voči druhému rodičovi potrestá sa odňatím slobody na tri až osem rokov.

Aj do Zákon o priestupkoch ${ }^{19}$ má v ust. $\$ 28$ do priestupkov na úseku práce a sociálnych vecí zakotvit' novú skutkovú podstatu priestupku s možnost’ou uložit' pokutu do $331 €$, a to v znení, že priestupku sa dopustí ten, kto:

a) nedodržiava súdom schválený rodinný plán

b) marí iné rozhodnutie v súvislosti so starostlivost'ou o maloletých, najmä súdom ustanovenú povinnost' alebo výchovné opatrenie a ochranné opatrenie

c) bezdôvodne marí kontakt maloletého diet'at'a s rodičom alebo neposkytuje informácie o maloletom diet’ati druhému rodičovi v zmysle osobitného zákona

d) zanedbáva maloletého najmä tým, že dlhšiu dobu si neplní rodičovské povinnosti, nie je s diet’at'om bez vážneho dôvodu v kontakte alebo ignoruje jeho základné potreby

\section{Záver}

Maloleté deti sú zranitel'né, preto potrebujú ochranu nielen od svojej rodiny, ale aj zo strany štátu. Túto úlohu by mali plnit’ aj súdy svojou konzistentnou rozhodovacou činnost’ou v súlade s najlepším záujmom diet’at’a, ktorá spĺn̆a základné požiadavky kladené na odôvodnenie súdneho rozhodnutia, rešpektujúc právo na súdnu ochranu.

\footnotetext{
18 zákon č. 300/2005 Z.z. Trestný zákon v znení neskorších právnych predpisov

${ }^{19}$ zákon č. 371/1990 Zb. o priestupkoch v znení neskorších právnych predpisov
} 


\section{PRÁVNE ROZPRAVY ON-SCREEN II. - Sekcia súkromného práva}

online vedecká konferencia - 13. november 2020

Zo zamýšl’aných legislatívnych zmien možno za prínosné vnímat' výslovné zakotvenie základnej zásady Zákona o rodine zdôrazňujúcej postavenie maloletého diet’at’a ako subjektu právnych vzt'ahov. Za menej vhodné možno považovat' navrhovaný výkon funkcie kolízneho opatrovníka neštátnymi subjektami a za nadbytočné zastupovanie maloletého diet’at'a ustanoveným právnym zástupcom popri kolíznom opatrovníkovi.

Vel'kou témou bude zakotvenie inštitútu rodinných plánov, ktorých presnú právnu úpravu je potrebné ešte precizovat' tak, aby spĺn̆ala atribút vykonatel'nosti. Prípadne je potrebné zvážit' ponechanie rodičovských dohôd a zavedenie rodičovských lánov po vzore Českej republiky.

Rozšírenie trestnoprávnej a zodpovednosti za priestupok bude prínosné vo vzt'ahu k zabezpečeniu realizácie práva diet'at'a a tomu korešpondujúcemu práva rodiča na pravidelný, rovnocenný a rovnoprávny styk, lebo trend bránenia $\mathrm{v}$ styku, programovania diet’at’a jedným rodičom proti tomu druhému rodičovi je v súčasnosti stúpajúci. Na to nadväzuje nefunkčný systém výkonu rozhodnutí vo veciach starostlivosti súdu o maloleté deti, ktorého zefektívnenie by malo byt' do budúcna pre zákonodarcu prioritou. $\mathrm{V}$ tomto smere možno pozitívne hodnotit' zakotvenie načrtnutých postihov pre rodičov, otázne len ostáva, či sa bude siahat' po týchto nástrojoch na potrestanie rodiča a či prax súdov bude príkladom a svojim spôsobom aj hrozbou pre všetkých programujúcich rodičov v tom smere, že si budú vedomí, že im hrozí nielen trestnoprávny postih, ale zverenie diet’at'a do starostlivosti toho druhého rodiča. Túto možnost' majú súdy aj v súčasnosti zakotvenú v ust. 25 ods. 4 Zákona o rodine, ale pristupuje sa k nej výnimočne a súdy ho takmer neaplikujú. V spojení s neúmernou dížkou konania je nastolený stav, že čoraz viac detí sa odcudzí od druhého rodiča do tej miery, že sa ich vzt'ah už nikdy nepodarí zreparovat' a dôsledky toho sú pre zdravý vývoj diet’at’a d’alekosiahle.

Celkovo sa ukazuje ako nevyhnutným prechod od tradičnej opatrovníckej justície, ktorá sa sústred'uje na vybavenie veci, teda na rozhodnutie vo veci po vykonaní potrebného dokazovania, čo v skutočnosti nemusí predstavovat' vyriešenie rodinného problému a zmenu v situácii diet’at’a, k modernej opatrovníckej justícii, ktorá je zameraná na riešenie rodinnej situácie tým, že zistí problém, zmierni konflikt $\mathrm{v}$ rodine a dovedie rodičov $\mathrm{k}$ schopnosti dohodnút' sa o ich diet’ati v súlade s jeho najlepším záujmom. 
PRÁVNE ROZPRAVY ON-SCREEN II. - Sekcia súkromného práva

online vedecká konferencia - 13. november 2020

\section{ZOZNAM BIBLIOGRAFICKÝCH ODKAZOV}

JURČOVÁ, M. Zastúpenie v súkromnom práve. 1. vydanie. Praha: C. H. Beck, 2012. 272 s. ISBN 978-80-7400-420-9

PAVELKOVÁ, B. Zákon o rodine. Komentár. 1. vydanie. Praha: C. H. Beck, 2011. 655 s. ISBN 978-80-7400-359-2

VOJČÍK, P. a kol. Občianske právo hmotné. Plzeň: Aleš Čeněk, 2012. 637 s. ISBN 978-807380-402-2

Dohovor o právach diet'at’a [online].[cit. 24.11.2020].URL:<https://www.unicef.sk/files/ dohovor_o_pravach_dietata.pdf $>$

$\mathrm{S}$ návrhom novej súdnej mapy sa už oboznamuje odborná verejnost' URL:< https://www.najpravo.sk/clanky/s-navrhom-novej-sudnej-mapy-sa-uz-oboznamuje-odbornaverejnost.html>. [online].[cit. 24.11.2020] 